УДК 159.923.2:159.923.3-027.21

DOI https://doi.org/10.26661/2310-4368/2021-1-9

\title{
ОБРАЗ «ЧОЛОВІКА» І «ЖІНКИ» У СВІДОМОСТІ ОСОБИСТОСТІ РІЗНОГО ВІКУ (КРОС-КУЛЬТУРНЕ ДОСЛІДЖЕННЯ)
}

\author{
Котлова Л. О. \\ кандидат психологічних наук, дочент, \\ доиент кафедри сочіальної та практичної психології \\ Житомирський державний університет імені Івана Франка \\ вул. Велика Бердичівська, 40, Житомир, Украӥна \\ orcid.org/0000-0003-2994-6724 \\ kotlova.lo@i.ua
}

Тичина I. М.

кандидат психологічних наук, доцент, декан соиіально-психологічного факультету

Житомирський державний університет імені Івана Франка

вул. Велика Бердичівська, 40, Житомир, Украӥна

orcid.org/0000-0001-6210-4145

iratychyna@gmail.com

\section{Прокудіна В. В.}

магістрантка спеціальності «Психологія»

Житомирський державний університет імені Івана Франка

вул. Велика Бердичівська, 40, Житомир, Украӥна

orcid.org/0000-0002-4070-2977

esenina_viktoriya@ukr.net

\begin{abstract}
Ключові слова: гендерні відмінності, культура, онтогенез, свідомість самосвідомість, стереотипи, уявлення.
\end{abstract}

Під впливом гендерних стереотипів, які існують у кожному суспільстві і формуються в контексті культури, історичного часу, у свідомості чоловіків і жінок виникає гендерна ідентичність. Але у психології розглядаються i внутрішні чинники утворення гендерної ідентичності, психологічні гендерні ролі; механізми утворення та конструювання гендерної і статевої ідентичності. Дуже важливим є формування образу «чоловік» і «жінка» саме в сучасної молоді, адже надалі буде відбуватися «викривлене» бачення та прийняття суспільства, яке матиме свої певні наслідки.

Дослідження розкрило головні відмінності між усвідомленням понять «чоловік» i «жінка» особистостями трьох національностей (українці, американці, китайці). Встановлено, що українці відразу ж асоціюють поняття «жінка» із зовнішніми рисами «красива», «ніжна», «сексуальна», «симпатична», а американці та китайці більше із внутрішніми рисами: «добра», «віддана», «чуйна», «розумна», «вірна», «турботлива»; китайці «прив'язують» образ жінки лише до «сімейного вогнища»: сім'ї, материнства, домашніх турбот, американці та українці більш вільні у своїх поглядах, тому не «прикріплюють» образ жінки до однісї сфери життєдіяльності; гендерні ролі, що притаманні чоловікам і жінкам трьох країн, не мають суттєвих відмінностей, окрім того, що китайці не виокремлюють жінок у професійних сферах: «вчителька», «психологиня», «менеджерка»; розмежування маскулінності, фемінності та андрогінності по трьом національностям дозволяє дійти висновку, що українцям властиві фемінність та андрогінність 
(більша кількість), у американців відсутні маскулінність і фемінність (усі 100\% досліджуваних мають андрогінний образ).

У досліджуваних представників КНР наявна маскулінність, фемінність і андрогінність у решти досліджуваних. Тобто, у китайців більш помітне розмежування образів; найбільш схильні до стереотипного мислення саме досліджувані представники народу КНР (у них найвищі показники серед досліджуваних трьох національностей); було виявлено, що стереотипне мислення більше виявляється в період юнацтва, ніж у ранньому дорослому віці. Це все ж пов'язано з віковими особливостями та набутим досвідом у період переходу між цими двома віковими періодами.

\title{
THE IMAGE OF "MAN" AND "WOMAN" IN THE MINDS OF INDIVIDUALS OF DIFFERENT AGES (CROSS-CULTURAL RESEARCH)
}

\author{
Kotlova L. $\mathbf{O}$. \\ PhD in Psychology, Associate Professor, \\ Associate Professor at the Department of Social and Practical Psychology \\ Zhytomyr Ivan Franko State University \\ Velyka Berdychivska str., 40, Zhytomyr, Ukraine \\ kotlova.lo@i.ua \\ orcid.org/0000-0003-2994-6724
}

Tychyna I. M.

PhD in Psychology, Associate Professor,

Dean of the Faculty of Socio-Psychology

Zhytomyr Ivan Franko State University

Velyka Berdychivska str., 40, Zhytomyr, Ukraine

orcid.org/0000-0001-6210-4145

iratychyna@gmail.com

Prokudina V. V.

Master's degree in Psychology

Zhytomyr Ivan Franko State University

Velyka Berdychivska str., 40, Zhytomyr, Ukraine

orcid.org/0000-0002-4070-2977

esenina_viktoriya@ukr.net

Key words: consciousness, culture, gender, gender identity, stereotypes.

\begin{abstract}
Under the influence of gender stereotypes that exist in every society and are formed in the context of culture, historical time, gender identity emerges in the minds of men and women. But in psychology, the internal factors of the formation of gender identity, psychological gender roles are also considered; mechanisms of formation and construction of gender and gender identity. The study revealed to us the main differences between the awareness of the concepts of "man" and "woman" of the personalities of these three nationalities. Among them are the main: Ukrainians immediately associate the concept of «woman» with the external features of «beautiful», «tender», «sexy», «pretty», and Americans and Chinese more with internal features «good», «loyal», «sensitive», «smart», «true», «caring», etc.

The Chinese "tie" the image of a woman only to the "family hearth": family, motherhood, domestic worries, Americans and Ukrainians are more free in their views, so do not "attach" the image of a woman to one area of life. Gender
\end{abstract}


roles, which are inherent in men and women of the three countries, do not differ significantly, except that the Chinese do not distinguish women in professional fields "teacher", "psychologist", "manager"; the distinction between macularity, femininity and androgyny by three nationalities - Ukrainians are characterized by femininity and androgyny (more), Americans do not have masculinity and femininity (all 100\% of respondents have an androgynous image).

The studied representatives of the PRC have masculinity, femininity and androgyny in the rest of the studied. That is, the Chinese have a more noticeable demarcation of images. The most prone to stereotypical thinking are the studied representatives of the people of China (they have the highest rates among the studied three nationalities); it was found that stereotypical thinking is more pronounced in adolescence than in early adulthood. However, this is due to age and experience gained during the transition between the two ages.

Постановка проблеми. На сучасному етапі в українській науці гендерна психологія набирає обертів. Вона характеризується збором емпіричних даних досліджень країн Європи та Америки, проведенням експериментальних досліджень, теоретичним осмисленням емпіричних фактів, початком крос-культурних досліджень, адаптуванням відомих методів психології для вивчення гендерної проблематики i розробкою специфічних гендерних методик. Вже на цьому етапі починають видаватися підручники на основі гендерних теорій і досліджень. Розпочато впровадження результатів гендерних досліджень у практику.

Гендерна психологія здебільшого розвивається у психології статевих і гендерних відмінностей. При цьому слабкою стороною і надалі залишається невелика кількість узагальнюючих теорій. Дослідження, які проводяться за різними напрямами, поки що не об'єднані жодною теоретичною базою чи спільною програмою. 3 іншого боку, приємним є факт все більшого зацікавлення гендерною проблематикою наших вчених-психологів.

У різних соціальних культурах чоловічими вважаються такі гендерні ролі як «лідер», «воїн», «скала», які пов'язані з характеристиками сильний, мужній, відповідальний, відважний, хоробрий, компетентний, владний, емоційно стриманий, помічник, а місце чоловіка - робота, кар'єра, $\mathrm{i}$, власне, добування грошей. Основними жіночими ролями $\epsilon$ «слабкість», «підлеглість», «берегиня» і основне місце жінки - сім'я, створення домашнього затишку і тепла.

На думку багатьох дослідників, найдієвішим механізмом утворення і відтворення гендерних стереотипів залишається яскраво виражена ієрархічність гендерних класів: жінці приписується менша вартість, аніж чоловікові. Це накладає свій відбиток на сприйняття якостей особистості чоловіка і жінки і наділяє усі можливі відмінності у гендерній ідентичності чоловіка і жінки смислами «добре» та «погано». В аналізі гендерних стере- отипів важливу роль відіграє виділення бінарних опозицій, що традиційно приписуються чоловікові/жінці: логічність/інтуїтивність; абстрактність/конкретність; свідомість/несвідомість; влада/підпорядкування; порядок/хаос; незалежність, індивідуальність/близькість, колективність; імпульсивність, активність/статичність, пасивність; непостійність, невірність, радикалізм/ постійність, вірність, консерватизм.

Під впливом гендерних стереотипів, які існують у кожному суспільстві і формуються в контексті культури, історичного часу, у свідомості чоловіків і жінок виникає гендерна ідентичність. Але у психології розглядаються і внутрішні чинники утворення гендерної ідентичності, психологічні гендерні ролі (П. Горностай) [4]; механізми утворення і конструювання гендерної і статевої ідентичності (О. Кочарян, Н. Терещенко) [5]. Визначено нормативну структуру симптомокомплексу «маскулінності/фемінності», особливості iii функціонування у нормі та патології. У дослідженнях I. Головньової та I. Найдовської розглядаються особливості трансформації гендерної ідентичності і іiї вплив на формування життєвого стилю жінок [3; 7].

Сучасні дослідження закордонних вчених (Hyde J.S, Mueller W., Silva T.H., van de Vijver) вказують на актуальність дослідження гендерних ролей і вплив культури на їх формування $[9 ; 11$; $13 ; 15]$. Як зазначають науковці, культура впливає на те, як ми сприймаємо людей протилежної статі, чого від них очікуємо, а також формує виникнення стереотипів сприйняття $[8 ; 10 ; 14]$.

Основною метою статті $\epsilon$ висвітлення результатів емпіричного дослідження особливостей сприйняття образу «чоловік» і «жінка» в осіб різних національностей юнацького та раннього дорослого віку.

Методи дослідження: емпіричні - опитувальник C. Бем (BSRI) та метод вільних асоціацій; соціальне опитування щодо гендерних стереотипів. 
Вибірка дослідження. У дослідженні брали участь 180 осіб (60 українців, 60 китайців, 60 американців). Це молоді працездатні люди (чоловіки і жінки), які навчаються/працюють, мають активну громадянську думку, власні цілі та певні досягнення. Вік досліджуваних $18-35$ років (юнацький $18-25$, ранній дорослий 26-35). Дослідження проводилось в онлайн-режимі з використанням платформи Google Form, яка містила всі методики українською та англійською мовами.

Виклад основного матеріалу дослідження. Слід звернути увагу, що у різних соціальних культурах жіночими вважаються такі гендерні ролі як «матір», «берегиня», «підлегла», що мають логічні подальші характеристики добра, ніжна, тепла, покірна, вразлива та емоційна. Чоловічими ж вважаються гендерні ролі «лідер», «воїн», «скала», які пов'язані 3 такими характеристиками: сильний, мужній, відповідальний, відважний, владний, емоційно стриманий. Отже, і місця «чоловіка» та «жінки» відрізняються: місце чоловіка - робота, кар'єра, i, власне, добування грошей, місце жінки - дім, усе, що навколо дому (сад, город), культурні заклади (музей, бібліотека, театр). Можна помітити, що образи «чоловіка» та «жінки» протилежні одне одному і водночас ніби доповнюють одне одного.

Образу «чоловіка» помітно менше у дослідженнях, аніж образу «жінки». Це можна пов'язати із феміністським рухом, адже українські жінки, запозичивши цю ідею із західної Свропи та Америки, особливо пропагують і піднімають цю «проблему» всюди, де тільки можливо. Однак в українському суспільстві за чоловіками традиційно закріплені важливі сфери суспільного життя та діяльності - політична, економічна, міждержавна, про що свідчать 3МІ, соціальні дослідження та сьогодення загалом. Чоловічий образ особливо набуває переваг у матеріалах, що висвітлюють політичну тематику. Тут журналісти зазвичай подають досить серйозний імідж чоловіка-політика - відповідно до його досягнень у політиці, у суспільному житті країни. Навіть кількісний аналіз свідчить, що найчастіше на сторінках періодики з'являються представники саме чоловічої статі $[1 ; 6]$.

Провівши дослідження за статево-рольовим опитувальником Сандри Бем [8], нами встановлено, що досліджуваним українцям не властива маскулінність. Лише у $10 \%$ наявна фемінність, а у більшості - андрогінність. Також у зазначеній вибірці було виділено 10 позитивних якостей: «Вміння співчувати», «Сердечність», «Щирість», «Надійність», «Розуміння інших», «Здатність допомогти», «Адаптивність», «Відданість», «Власна позиція» та «Вміння дружити».

Категоріонально розмежовані слова-асоціації

\begin{tabular}{|l|l|}
\hline \multicolumn{1}{|c|}{ Категорії } & \multicolumn{1}{c|}{ Слова-асоціації } \\
\hline «Статус» & Чоловік, дружина, мати, друг \\
\hline «рофесія/робота» & $\begin{array}{l}\text { Вчителька, менеджер, бізнес- } \\
\text { мен, модель }\end{array}$ \\
\hline «Зовнішність/якості» & $\begin{array}{l}\text { Добра, красива, мужній, } \\
\text { надійний }\end{array}$ \\
\hline «Обов’язки» & $\begin{array}{l}\text { Прибирання, домашні справи, } \\
\text { готування їжі }\end{array}$ \\
\hline «Хобі» & $\begin{array}{l}\text { Баня, риболовля, шопінг, } \\
\text { навчальні курси }\end{array}$ \\
\hline «Інтим» & Симпатія, секс, любов, запах \\
\hline «нше» & Парфуми, каблуки, м’язи \\
\hline
\end{tabular}

Щодо результатів досліджуваних американців, то можемо сказати, що якостей за опитувальником С. Бем, які набрали найбільшу кількість позитивних відповідей як чоловіків, так і жінок, аж 13: «Вміння поступатися», «Схильність захищати свої погляди», «Життєрадісність», «Здатність до лідерства», «Турбота про людей», «Щирість», «Надійність», «Розуміння інших», «Швидкість у прийняті рішень», «Співчуття», «Сердечність/ теплота», «Важливість», «Індивідуалізм». Досліджуваним не властива ані маскулінність, ані фемінність. В усіх досліджуваних американців виявлена андрогінність.

У досліджуваних китайців маємо найбільшу кількість якостей - 18: «Вміння співчувати», «Вміння поступатися», «Захист своїх поглядів», «Життерадісність», «Піддатливість лестощам», «Турбота про людей», «Сердечність», «Щирість», «Самодостатність», «Вміння втішити», «Привабливість», «Сердечність», «М'якість», «Індивідуалізм», «Любов до дітей», «Спокійність» і «Вміння дружити».

Якщо звести та порівняти результати досліджуваних трьох національностей, то бачимо 4 спільні якості, які виділили досліджувані: «Вміння співчувати», «Щирість», «Розуміння інших» та «Сердечність». На нашу думку, ці характеристики $є$ виявом суспільної зрілості, тому що вони спрямовані на соціум та життя в ньому.

Здійснивши дослідження серед народів України, США та КНР методом вільних асоціацій, ми отримали результати, які представлені в таблиці 1. Усі слова-асоціації ми віднесли до семи категорій: «Статус», «Професія/робота», «Зовнішність/якості», «Обов’язки», «Хобі», «Інтим», «ІІнше».

Результати досліджуваних українців (рис. 1.) свідчать, що поняття «чоловік» набрало найбільшу кількість асоціацій по двох категоріях - «Статус» (28) та «Зовнішність/якості» (58). Найменшу кількість отримали категорії «Інтим» (8) та «Обов'язки» (12). Щодо образу «жінки», то най- 
більшу кількість набрали три категорії: «Зовнішність/якості» (73), «Статус» (32) та «Обов'язки» (22), а найменшу - «Інше» (3), «Хобі» (4), «Професія» (6).

Таким чином, чоловіки i жінки викликають найбільше асоціацій, пов'язаних із зовнішніми рисами та якостями особистості (до образу «жінки» частіше відносили жіночність, красу, ніжність, до образу «чоловіка» - мужній, сильний, цілеспрямований).

Порівнюючи два вікових періоди (юнацький вік і вік ранньої дорослості), можна сказати, що в юнацькому віці найбільша кількість асоціацій припадає на категорію «Зовнішність» - 72 шт., а під час ранньої дорослості ця кількість зменшується до 57 шт., категорії «Статус» та «Обов’язки» навпаки - зростає (рис. 2). Це може бути пов'язано 3 віковими характеристиками та життєвим досвідом. Адже в період ранньої дорослості людина зустрічає свого життєвого партнера, 3 яким зароджується сім'я, а відповідно з'являються нові сімейні статуси та обов'язки.

Щодо результатів досліджуваних США, то було виявлено, що поняття «чоловік» набрало найбільшу кількість асоціацій по двох категоріях - «Професія/робота» (47) та «Зовнішність/ якості» (48). Найменшу кількість отримали категорії «Хобі» (10), «Інше» (10) та «Обов'язки» (8). Щодо образу «жінки», то знову ж таки найбільшу кількість набрали ті ж категорії: «Зовнішність/якості» (51), «Професія/робота» (30), а найменшу «Інтим» (10), «Обов’язки» (12), «Хобі» (13).

Отже, у чоловіків і жінок найбільше асоціацій, пов'язаних із зовнішніми рисами та якостями особистості (до образу «жінки» частіше відносили жіночність, вірність, красива, до образу «чоловіка» - мужній, надійний, розумний), а також із професійною діяльністю (до чоловічого образу віднесли професії менеджера та програміста, до жіночого - актрису та вчителя).
Порівнюючи вікові періоди (юнацький вік і вік ранньої дорослості), можна сказати, що в юнацькому віці найбільша кількість асоціацій припадає на категорію «Зовнішність» - 49 шт., а по категоріях «Статус», «Професія/робота» та «Обов'язки» кількість асоціацій «зростає».

Аналізуючи результати досліджуваних КНР, встановлено, що поняття «чоловік» набрало найбільшу кількість асоціацій по трьох категоріях «Статус» (38), «Професія/робота» (52) та «Зовнішність/якості» (30). Найменшу кількість отримали категорії «Інше» (3) та «Хобі» (5). Щодо образу «жінки», то найбільшу кількість набрали три категорії: «Зовнішність/якості» (63), «Статус» (38) та «Обов'язки» (42), а найменшу - «Інше» (3), «Хобі» (1), «Професія» (4) та «Інтим» (5). Таким чином, і чоловіки, і жінки викликають найбільше асоціацій, пов'язаних із зовнішніми рисами та якостями особистості (до образу «жінки» частіше відносили тендітність, краса, хазяйновитість, образу «чоловіка» - розумний, сильний, надійний), а також зі статусом (образу «жінки» належали дружина, мати, сестра, образу «чоловіка» - батько, чоловік, син).

Порівнюючи результати методу вільних асоціацій досліджуваних усіх трьох національностей, то поняття «чоловік» (рис. 2) набрало найбільшу кількість асоціацій по трьох категоріях: «Зовнішність/якості» - 134 шт. (українці - 58 шт., американці - 48 шт., китайці - 30 шт.), «Професія/ робота» - 117 шт. (українці - 18 шт., американці 47 шт., китайці - 52 шт.) і «Статус» - 81 шт. (українці - 28 шт., американці - 15 шт., китайці - 38 шт.).

Найчастіше до образу «чоловіка» за категорією «Зовнішність/якості» відносилися такі асоціації: мужній, сильний, цілеспрямований, розумний, надійний; за категорією «Професія/робота» - бізнесмен, менеджер, лікар, інженер, науковець; за категорією «Статус» - чоловік, батько, друг, син.

Поняття «жінка» (рис. 3) набрало найбільшу кількість асоціацій по трьох категоріях: «Зовніш-

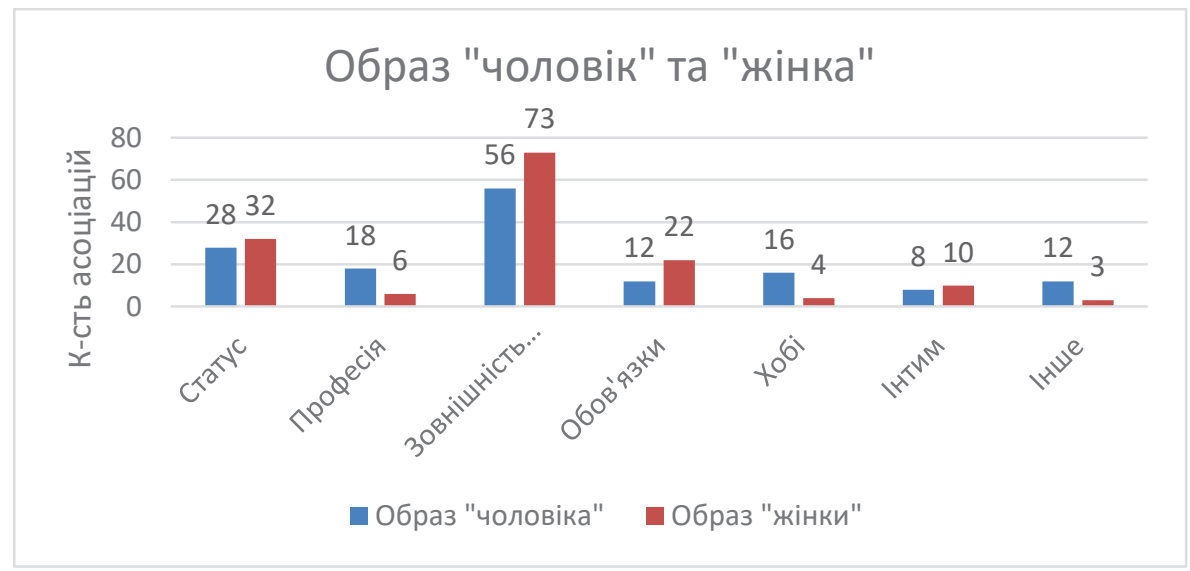

Рис. 1. Асоціації до образу «чоловік» і «жінка» по категоріях (відповіді українців) 
ність/якості» - 187 шт. (українці - 73 шт., американці - 51 шт., китайці - 63 шт.), «Статус» 79 шт. (українці - 32 шт., американці - 15 шт., китайці - 32 шт.), «Обов'язки» - 76 шт. (українці - 22 шт., американці - 12 шт., китайці - 42 шт.). Найчастіше до образу «жінка» за категорією «Зовнішність/якості» відносилися такі асоціації: жіночна, ніжна, красива, сексуальна, тендітна, добра; за категорією «Статус» - дружина, мама, сестра, коханка, господиня; за категорією «Обов' язки» - хатні обов'язки, домашні справи, готування їжі, прибирання.

Отже, з огляду на результати методу вільних асоціацій, можна сказати про те, що на асоціації до образів «чоловіка» і «жінка» великий вплив мають гендерні стереотипи.

В юнацькому віці найбільша кількість асоціацій припадає на категорію «Зовнішність» 167 шт. У юнацькому віці категорії «Статус»,
«Професія/робота» та «Обов'язки» «зростають» і мають найбільші показники.

Висновки. На свідомість людини впливає багато різних чинників, одним із головних $€$ культура. Певна культура породжує маси та становить характерний соціум. Всередині соціуму знаходяться орієнтири, цінності, знання, а також народжуються стереотипи. Вони надходять до нас із соціуму під час розвитку самосвідомості. Аналізуючи теоретичну модель, можна стверджувати, що через стереотипність мислення ми маємо певні вже сформовані 3 дитячого віку уявлення про світ, що нас оточує. Тому можемо стверджувати, що велике значення відіграє духовна культура, традиції та звичаї певного народу.

Розкрито головні відмінності між усвідомленням понять «чоловік» і «жінка» особистостей цих трьох національностей. Серед них основні: українці відразу ж асоціюють поняття «жінка» із зовнішніми рисами «красива», «ніжна», «сексу-

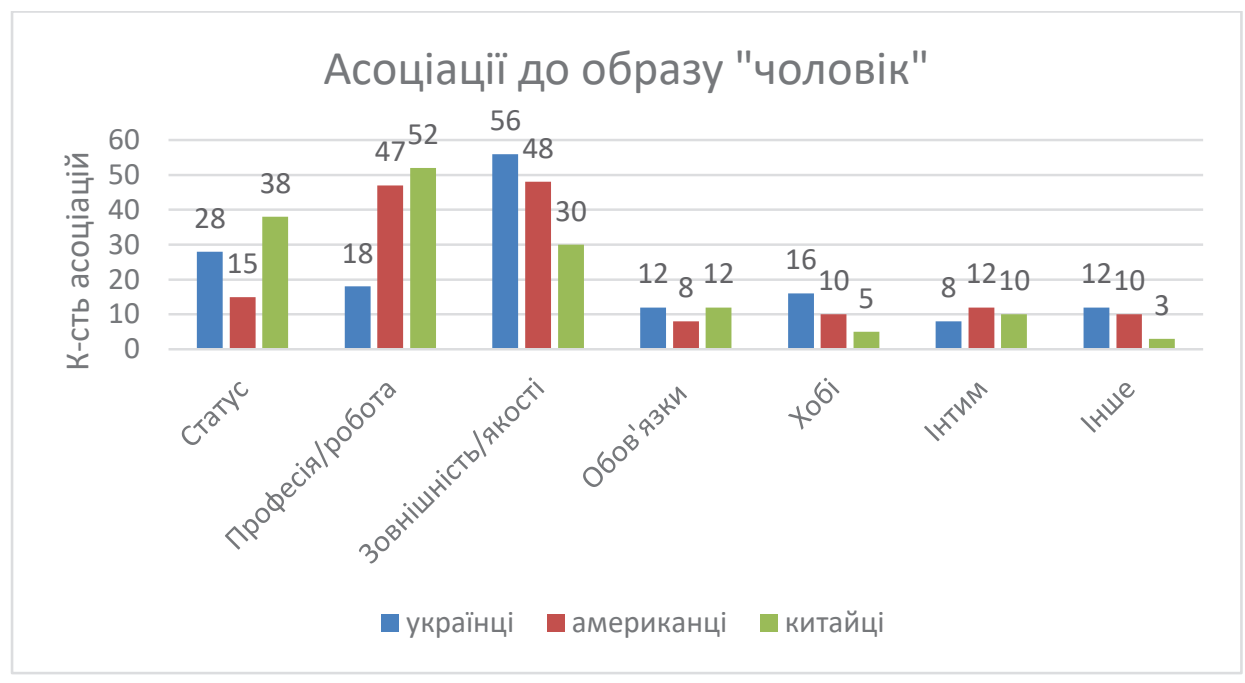

Рис. 2. Асоціації до образу «чоловік» по категоріях

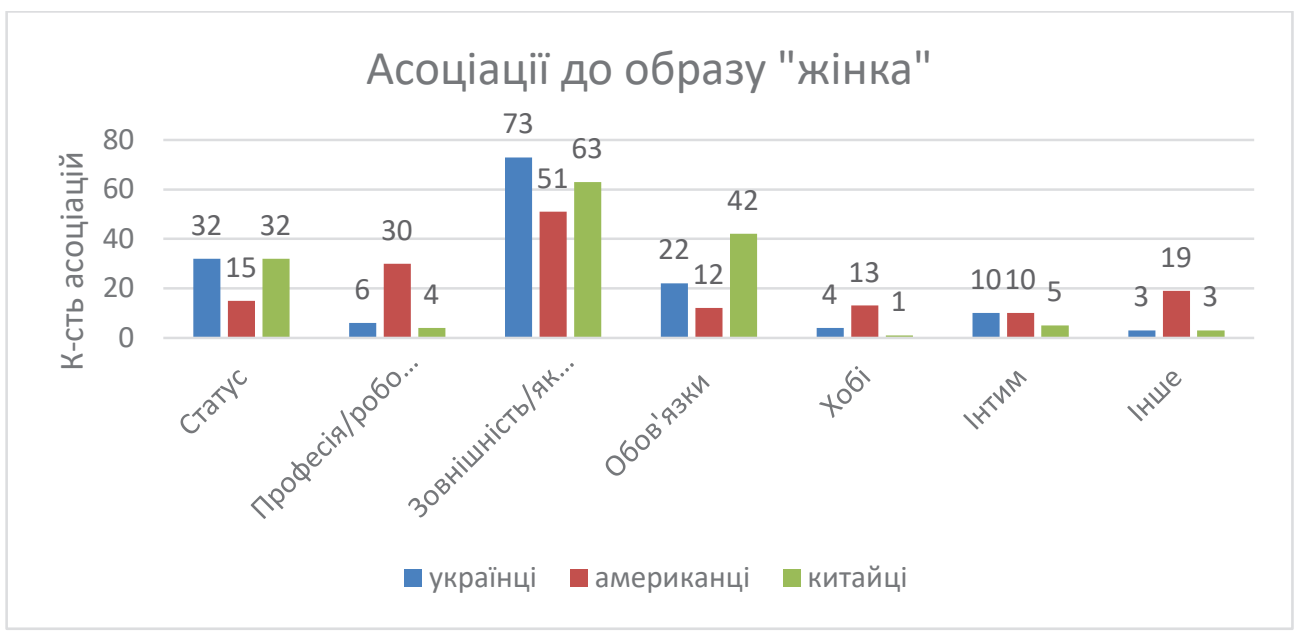

Рис. 3. Асоціації до образу «жінка» по категоріях 
альна», «симпатична», а американці та китайці більше iз внутрішніми рисами - «добра», «віддана», «чуйна», «розумна», «вірна», «турботлива»; китайці «прив'язують» образ жінки лише до «сімейного вогнища» - сім’’̈, материнства, домашніх турбот, американці та українці більш вільні у своїх поглядах, тому не «прикріплюють» образ жінки до однієї сфери життєдіяльності;

- гендерні ролі, що притаманні чоловікам та жінкам трьох країн, не мають суттєвих відмінностей, окрім того, що китайці не виокремлюють жінок у професійних сферах - «вчителька», «психологиня», «менеджерка»;

- розмежування маскулінності, фемінності та андрогінності по трьом національностям: українцям властиві фемінність та андрогінність (більша кількість), в американців відсутні маскулінність і фемінність (усі 100\% досліджуваних мають андрогінний образ). У досліджуваних представників КНР наявна маскулінність, фемінність і андрогінність у решти досліджуваних. Тобто, у китайців більш помітне розмежування образів;

- найбільш схильні до стереотипного мислення саме досліджувані представники народу КНР (у них найвищі показники серед досліджуваних трьох національностей);

- було виявлено, що стереотипне мислення більше виявляється в період юнацтва, ніж у ранньому дорослому віці. На нашу думку, це пов'язано з віковими особливостями та набутим досвідом у період переходу між цими двома віковими періодами.

Проведене дослідження не вичерпує всіх аспектів досліджуваної проблеми. Перспективи подальших досліджень (науково-дослідної роботи) вбачаємо у розробці, впровадженні та перевірці ефективності розробленої корекційно-розвивальної програми «Гендерна чутливість: мистецтво взаємин 3 «ним» і «нею»».

\section{ЛІТЕРАТУРА}

1. Волобуєва А. Гендерні стереотипи у пресі: теоретичний аспект. Образ. 2017. Вип. 2. С. 95-101. Режим доступу: http://nbuv.gov.ua/UJRN/obraz 2017214.

2. Говорун Т.В., Кікінежді О.М. Гендерна психологія. К. : Видавничий центр «Академія», 2004. 308 с.

3. Головньова І.В. Особливості спрямованості особистості, що впливають на ефективність управлінської діяльності: гендерні відмінності. Вісник Харківського національного педагогічного університету імені Г.С. Сковороди. Філософія. 2012. № 4. С. 61-68.

4. Горностай П.П. Социализация личности и психологические роли. Теоретические и прикладные вопросы психологии : материалы юбилейной конференции «Ананьевские чтения-97». Вып. 3. СПб, 1997. C. 325-330.

5. Кочарян А.С., Терещенко Н.Н. Полоролевая идентичность у женщин. Вісник Харківського університету. Серія: Психологія. 2000. № 498. С. 81-87.

6. Кушнір Н.В. Гендерна експертиза трудового законодавства та стан ії реалізації в Україні. Науковий вісник Херсонського державного університету. Серія: Юридичні науки. 2016. Вип. 6(1). С. 170-173. Режим доступу: http://nbuv.gov.ua/UJRN/Nvkhdu jur 2016 6(1) 44.

7. Найдовська І.В. Вплив статево-рольового розвитку жінок на особливості їх життєвого стилю : дис. канд. психол. наук: 19.00.01. / Київ. Нац. ун-т ім. Т. Шевченка. Київ, 2002. 190 с.

8. Bem S. The Lenses of Gender: Transforming the Debate on Sexual Inequality. Yale University Press, 1993. 256 p. Режим доступу: https://www.jstor.org/stable/j.cttlnq86n.

9. Gender Equality and Women's Development in China. Режим доступу: www.china.org.cn/english/2005/ Aug/139404.htm.

10. Harrison L.E, Huntington S.P. Culture matters: how values shape human progress. Basic Books, New York. 2000.

11. Hyde J.S The gender similarities hypothesis. American Psychological Association. 2005. Vol. 60, № 6, P. 581-592. DOI: 10.1037/0003-066X.60.6.581.

12. Joanna McMillan. Sex, science and morality in China, London/New York : Routledge, 2006.

13. Mueller W., Silva T.H., Almeida J.M. et al. Gender matters! Analyzing global cultural gender preferences for venues using social sensing. EPJ Data Sci. 2017. Vol. 6, № 5. Режим доступу: https://doi.org/10.1140/ epjds/s13688-017-0101-0.

14. Population Census Office and National Bureau of Statistics of China, Zhongguo 2010 nian renkou pucha ziliao. Beijing : China Statistics Press, 2012.

15. Van de Vijver, F.J.R. Cultural and Gender Differences in Gender-Role Beliefs, Sharing Household Task and Child-Care Responsibilities and Well-Being Among Immigrants and Majority Members in The Netherlands. Sex Roles. 2007. Vol. 57, Р. 813-824. Режим доступу: https://doi.org/10.1007/ s11199-007-9316-z. 


\section{REFERENCES}

1. Volobuieva A. (2017) Genderni stereotypy u presi: teoretychnyi aspekt [Gender stereotypes in the press: a theoretical aspect]. Obraz, vol. 2. P. 95-101. http://nbuv.gov.ua/UJRN/obraz 2017214.

2. Gornostay P.P. (1997) Sotsializatsiya lichnosti i psihologicheskie roli [Socialization of personality and psychological roles]. Proceedings of the Theoretical and applied questions of psychology : materials of the anniversary conference "Ananiev Readings-97" (Russia, St Petersburg, 1997), St. Petersburg : SPb, p. 325-330.

3. Holovnova I.V. (2012) Osoblyvosti spriamovanosti osobystosti, shcho vplyvaiut na efektyvnist upravlinskoi diialnosti: henderni vidminnosti [Peculiarities of personality orientation that affect the effectiveness of management: gender differences]. Bulletin of GS Skovoroda Kharkiv National Pedagogical University. Philosophy, № 4, p. 61-68.

4. Hovorun T.V., Kikinezhdi O.M. (2004) Henderna psykholohiia [Gender psychology]. K. : Vydavnychyi tsentr "Akademiia" (in Ukrainian).

5. Kocharyan A.S., Tereschenko N.N. (2000) Polorolevaya identichnost u zhenschin [Gender identity in women]. Bulletin of Kharkiv University. Psychology series, № 498, p. 81-87.

6. Kushnir N.V. (2016) Henderna ekspertyza trudovoho zakonodavstva ta stan yii realizatsii v Ukraini [Gender examination of labor legislation and the state of its implementation in Ukraine]. Scientific Bulletin of Kherson State University. Series: Legal Sciences. vol. 6, № 1, p. 170-173. http://nbuv.gov.ua/UJRN/ Nvkhdu jur_2016_6(1)_ 44.

7. Naidovska I.V. (2002) Vplyv statevo-roljovogho rozvytku zhinok na osoblyvosti jikh zhyttjevogho stylju [Influence of sexual and role development of women on features of their lifestyle]. (PhD Thesis). Kyiv : National University of Taras Shevchenko.

8. Bem S. (1993). The Lenses of Gender: Transforming the Debate on Sexual Inequality. Yale University Press, 256 p. https://www.jstor.org/stable/j.cttlnq86n.

9. Gender Equality and Women's Development in China. www.china.org.cn/english/2005/Aug/139404.htm.

10. Harrison L.E., Huntington S.P. (2000) Culture matters: how values shape human progress. Basic Books, New York.

11. Hyde J.S. (2005) The gender similarities hypothesis. American Psychological Association. Vol. 60(6). P. 581-592. DOI:10.1037/0003-066X.60.6.581.

12. Joanna McMillan. (2006) Sex, science and morality in China, London/New York, Routledge.

13. Mueller W., Silva T.H., Almeida J.M. et al. (2017) Gender matters! Analyzing global cultural gender preferences for venues using social sensing. EPJ Data Sci. Vol. 6, № 5. https://doi.org/10.1140/epjds/ s13688-017-0101-0.

14. Population Census Office and National Bureau of Statistics of China, Zhongguo 2010 nian renkou pucha ziliao. (2012). Beijing : China Statistics Press.

15. Van de Vijver F.J.R. (2007) Cultural and Gender Differences in Gender-Role Beliefs, Sharing Household Task and Child-Care Responsibilities and Well-Being Among Immigrants and Majority Members in The Netherlands. Sex Roles. Vol. 57, P. 813-824. https://doi.org/10.1007/s11199-007-9316-z/ 